given to the various connexions of the Middle East with Africa, Arabic sources for the history of Africa, problems of Islamic expansion in Africa, Semitic origins of traditional Ethiopian civilization, and the unifying role of the Indian Ocean and the Red Sea. The rapid growth of Istael's connexions with the new states of East and West Africa has stimulated interest in African studies south of the Sahara, so that Bantu languages (with the emphasis on Swahili) are now being taught in addition to Arabic, Geez, and Amharic. A study is also being made of African ethnology, sociology, and art, the role of Christianity, and modern economic problems.

\title{
Centre Universitaire Rumuri à Usumbura
}

L'ouverture de la première année académique du Centre Universitaire Rumuri eut lieu sur la colline Kiriri le 28 octobre 1960. Une Faculté de Philosophie et Lettres et une Faculté de Sciences économiques, politiques et sociales accueillirent vingt-quatre étudiants. Les matières enseignées comportent l'Introduction à la sociologie politique, et Problèmes spéciaux de sociologie politique africaine, par Monsieur M. d'Hertefelt, et Histoire de l'Afrique et Structures et institutions traditionnelles de l'Afrique, par Monsieur A. Doutreloux.

\section{Special African number of 'Diogenes'}

A SPECIAL number of the journal Diogenes (January-March 1962 ), published under the auspices of the Conseil International de la Philosophie et des Sciences Humaines with the aid of Unesco, has been devoted to a series of articles on African subjects as follows :

De la négritude. Psychologie du Négro-africain

Religion, épopée, histoire. Notes sur les fonctions latentes des cultes dans les civilisations du Benin

Les concepts de prose littéraire africaine

Incidences socio-économiques sur la poésie noire d'expression portugaise

Le rôle spirituel et social de la femme dans la société soudanaise traditionnelle

La famille africaine et son adaptation à la vie urbaine

Pour une histoire de l'Afrique

Humanisme et négritude. Notes sur le roman afro-américain contemporain

Diogenes is published quarterly, under the direction of M. Roger Caillois, in French, English, Spanish, and Arabic, and may be ordered from booksellers or from Librairie Gallimard, Service abonnement, 5 rue Sébastien-Bottin, Paris viIe. The subscription is $18 \mathrm{NF}$ for France and Union Française, and $23 \mathrm{NF}$ for other countries.

\section{Special Issue of 'Anthropologica'}

THIs journal has issued a special Africa number at the end of March ${ }^{\text {1962, entitled 'Power }}$ in Complex Societies in Africa', edited by Ronald Cohen. The book review section is also devoted to recent contributions to the same problem. Summaries appear in French of English articles, and vice versa. Contents are as follows:

L'Accord de clientèle et l'organisation politique au Burundi

Power in Ruanda

The Analysis of Conflict in Hierarchical Systems: An Example

from Kanuri Political Organization

The Development of Local Government in a Nigerian Township

Accommodation and Conflict in an African Peri-urban Area
A. A. Trouwborst

Helen Codere

Ronald Coken

Simon Ottenberg

Peter C.W. Gutkind 
The price for a single number is $\$ 2.50$. Copies can be ordered from Joseph-E. Champagne, O.M.I., The Canadian Reseatch Center for Anthropology, Oblate Ave., Ottawa, Ontario, Canada.

\section{Exhibition of African Art in Edinburgh}

AN exhibition of African art in the Royal Scottish Museum, Edinburgh, from 24 February to 24 March, was organized under the auspices of the Munro Lectureship Foundation by the Department of Social Anthropology of Edinburgh University. Most of the exhibits were drawn from the collection of the Royal Scottish Museum, which gave its very generous cooperation in holding the exhibition; other loans were made by the British Museum, Glasgow Museum and Art Galleries, and private collectors.

The theme of the exhibition was the social and cultural context of African art. The following public lectures were given in conjunction with it: Mr. G. I. Jones on 'The Artist and the Community', Dr. R. E. Bradbury on 'The Art of Benin and Ife: (I) Artists and Patrons, (2) Art, Religion, and Society', Dr. M. J. Ruel on 'Convention in African Art'.

A catalogue was prepared for the exhibition by M. J. Ruel, some copies of which are still available.

\section{Linguistic Conference at the University of Dakar}

A Linguistic Conference, organized jointly by the University of Dakar and the West African Languages Survey and under the patronage of the President of the Senegal Republic, was held from 12 to 16 April. The programme was under the joint direction of Professors J. Berry and J. H. Greenberg; Professor R. G. Armstrong is the field director of the West African Languages Survey. Papers on a variety of linguistic topics were read in English and French and study groups were formed to discuss aspects of the Senegal-Guinea, Mande, Kwa, and Gur languages. There were eleven African participants among the total of forty-one from universities in Africa, Europe, and the United States.

\section{Establishment of the Institute of African Studies at the University of Ghana}

THE Institute of African Studies at the University of Ghana at Legon has at present a staff of five Research Fellows and a Director. There are three linguists, an historian, and a musicologist, but it is hoped to add to these in $1962-3$ an economist, a social anthropologist, a specialist in Arabic and Hausa, and an Islamic historian. A Music and Arts Division of the Institute has been created and will have initially four Research Fellows-two for music, one for dance and art, and one for literature. In addition the Institute hopes to invite a number of Visiting Professors and Lecturers from Britain, America, Russia, Mali, and other parts of Africa to give courses or open lectures in their own special fields. Associate membership of the Institute will be offered to members of teaching departments as well as to scholars abroad who might want to visit Ghana.

The present members of the Institute are carrying out research projects in Ghana in their own fields. Investigations into musicological problems have continued as well as ethnohistotical research into the formation of states, trade routes, and allied historical subjects. One of the three linguists is working on Dagbani and will shortly begin a survey of the languages of Northern Ghana. The second linguist is working on Akan, and the third on Guan, Togo Remnant languages, and Ewe. The last has been co-operating with the historian in the Institute and an archaeologist on investigations into Guan-Mande settlements. The Institute has been supporting research by members of teaching departments on the basis of individual applications; so far most of the requests for assistance have come from the Departments of History and Philosophy. As soon as funds are available the Institute hopes 